\title{
Re-Imported Literature or Double Domestication: Shizuko's Daughter by Kyoko Mori
}

Hiroko Inose

Dalarna University

\section{Introduction}

When Kyoko Mori's novel Shizuko's Daughter (originally published in U.S. in I993) was translated and published in Japan in I995, the following copy was written on its cover: "A work of new, re-imported Japanese literature: Kyoko Mori writes a story of love in Kobe, a city full of beautiful flowers - it touches your soul ." The original English version had won such awards as the ALA Best Book for Young Adults and New York Times Notable Book. The Japanese translation was also successful, so in I999, it was reprinted as paperback. The translation was by Makiko Ikeda, given that Mori apparently had "refused" (Masubuchi, I996, p. 94) to translate the novel into Japanese herself.

Whether the expression "New, re-imported Japanese literature" was appropriate or not, it definitely marked the beginning of a new phenomenon in the Japanese literary landscape, which would later be called ekkyo bungaku (literature that crosses the border). The genre includes works written in Japanese by nonJapanese authors, as well as works written by Japanese authors but in non-Japanese languages. The term ekkyo bungaku is not

I My translation from Japanese: 史上初、逆輸入の新しい日本文学 美 しい花に彩られた神戸を背景にキョウコ・モリが緅る魂を摇さぶる愛 の物語

How to cite this book chapter:

Inose, H. 202 I. Re-Imported Literature or Double Domestication: Shizuko's Daughter by Kyoko Mori. In: Jonsson, H., Berg, L., Edfeldt, C. and Jansson, B. G. (eds.) Narratives Crossing Borders: The Dynamics of Cultural Interaction. Pp. 255-274. Stockholm: Stockholm University Press. DOI: https://doi.org/IO.I6993/bbj.l. License: CC-BY 4.0 
clearly defined, and it sometimes also includes non-Japanese authors writing about fiction that takes place in Japan (e.g. Ogawa, 2009 , p. I I 5), thus indicating that the "border" to be crossed is not only language, but culture as well.

The author Kyoko Mori was born in Kobe (Japan) in 1957 and grew up there until the age of 20 , when she moved to U.S. for her studies. She did not go back to Japan for I 3 years, and by the time she published her first novel, Shizuko's Daughter, she had already become an American citizen, writing her works in English. However, the Japanese market seems to have received the novel as a part of Japanese literature (Masubuchi, I996). As the abovementioned copy "New, re-imported Japanese literature" indicates, the publisher intended to sell it as "literature that came back" to Japan, something new and yet familiar at the same time. The novel had a different reception in Japanese literary academia however, where the author was positioned as an ethnic minority writer within U.S. literature. She is often criticized for recreating exoticism about Japan, writing according to the expectations held by American readers (Narasaki 2005; Watanabe 2009).

But if the novel simply reproduces stereotypical images of Japan and Japanese people held by American readers, as some researchers argue, should that not be perceived by Japanese readers as unnatural description of their own society and culture, - and why, then, was it so successful in Japan? Was there any role played by the translation for the text to be more easily acceptable by Japanese readers? For this text to first cross the cultural border to the U.S., and then to cross the language border back to Japan, what had to happen? These questions seem to be relevant if we see how the novel was received in U.S., where it was highly recommended to young readers as learning material about a different culture (Zitlow and Stover, I998). So, on the one hand, the novel is expected to offer authentic information about Japanese culture and people. On the other hand, the information provided there has been criticized in Japanese academia for catering to western expectations. Finally, the Japanese version was not presented to the market as an example of how Japan was seen abroad, but as a story of love (between mother and daughter) in Kobe, as the copy stated. In other words, it was presented like any other story 
that takes place in Japan written by a Japanese writer (though in fact she was already an American national), but originally written in English.

The present paper focuses on the novel Shizuko's Daughter as a case study of the text crossing borders at various times - culturally from Japan to U.S. and linguistically from English to Japanese but the original English version being written by an author whose native language was (at least at one point) Japanese. After the introduction, a brief outline of the novel is given, pointing out its closeness to an autobiography, and therefore the possibility of the author's language choice being related to the issue of personal identity. Part three will discuss how this novel is positioned within the literary spheres of Japan and the U.S., thus creating different expectations to fulfil. Part four studies the translation of the text into Japanese. Using various examples, it will analyse the role of translation in fulfilling gaps that occur in the case of reimported texts. The fifth part is the conclusion, which reconsiders the meaning of texts travelling back and forth between cultures and languages.

\section{Shizuko's Daughter}

Shizuko's Daughter is a work of fiction, though there are many elements that overlap with the life of the author. The protagonist, Yuki, is a I2-year-old girl who lives in Kobe, a city in the western part of Japan. At the beginning of the novel, Yuki's mother Shizuko commits suicide at home. Shizuko leaves a note to her daughter assuring that she loves her and kills herself in order not to be a burden for her. Shizuko had been deeply unhappy because her husband Hideki had been having an affair for many years and was almost never at home. Neither could she get a divorce, as it was customary in Japan in the I970s to leave the children with their father, given that women often did not have a profession or financial independence. A divorce would have meant that she would lose Yuki.

Soon after Shizuko's death Hideki remarries his lover, and Yuki has to live with her father and new stepmother. Yuki's father and stepmother are depicted as caricatures of men and women in the Japanese traditional patriarchal system, with its internalised 
sexism, and are living lies in order to keep face. Yuki cannot get over the death of Shizuko, who was so different from the stepmother in her character - Shizuko was sincere, artistic and wise. Yuki does not forgive the father who caused Shizuko's death, and refuses to forget the past, rejecting contact with her parents. This repulsion is mutual, especially between Yuki and her stepmother, who often gets hysterical. Yuki is alone in the house without love or care. The only refuge is Shizuko's family, Yuki's grandparents, aunt and uncles - but her father and stepmother forbid Yuki to see them except on rare special occasions. They do not want others to think Yuki is missing her late mother's family because of uncaring parents. Yuki, who shows excellent performance at school, decides to leave home as soon as she graduates from high school, by choosing to go to a university in Nagasaki, far away from Kobe. The story ends with Yuki finally being able to leave the past behind - moving into adulthood carrying the memory of Shizuko but not being dominated by it.

Though it is a novel, the similarities between the lives of Mori and Yuki are undeniable. Mori's mother died of suicide when Mori was I 2 years old. In her autobiography, The Dream of Water (I995), Mori explains how her mother, Takako, must have even considered killing her two children (Mori and her younger brother) and herself in order to escape from her profound unhappiness. After Takako's death, Mori's father soon remarried his long-time lover, and Mori lived with him and the stepmother until she left Japan for the U.S. at the age of 20 . This move was not only to study abroad for several years, but Usui (2002, p. 6I) states, "Mori herself confesses that she possesses neither father nor country, nor a close family, since her home country is controlled by the patriarchy from which she is culturally exiled". It was a decision to leave the past and cut the unwanted roots. She did not go back to Japan for the next $\mathrm{I} 3$ years, and even that return, after so many years, was only a several-week visit connected to her work.

Various studies point out (e.g. Masubuchi I996; Watanabe 2006) the autobiographical characteristic of Shizuko's Daughter. This characteristic might be an important element when we consider the author's choice of language.

Mori herself comments that she only considers herself an American, and not a Japanese writer, as she writes only in English 
and does not identify with the Japanese literary tradition (Mori, 2000 , p. I4I). Her choice of language, though, might not only be based on the fact that she had studied literature and was trained to be a writer in English. She comments very negatively on the sexism and ambiguity (and therefore dishonesty) embedded in her once-native language, Japanese. She claims that the feminine Japanese language used in daily communication forces her to be "elaborately polite, indirect, submissive and unassertive", and that "(T)here is no way I can sound intelligent, clearheaded, or decisive." She describes how she never talks to a male Japanese colleague in Japanese, as: “(T)he language I use should not automatically define me as second best” (Mori, I997, p. I2).

This strong accusation against the Japanese language could be one of the reasons for Mori to choose another language to express herself. For bilingual authors, the choice of language is deeply related to their identity, especially when writing autobiographies (Pavlenko 200I; Inose 20I6), and it might apply to Mori as well. Mori is known to have refused to translate the novel into Japanese herself (Masubuchi, I996, p. 94; Watanabe, 2006, p. 47). This might simply be due to the fact that she was no longer used to writing in Japanese, and as Narasaki (2005, p. 76) suggests, the accuracy and the depth of her knowledge of the Japanese language was questionable. However, it also seems possible that the author found that she could not self-translate her identity as expressed in one language into another, as this would require her to express the other part of herself that she had decided to leave behind when she left Japan. If the part of her identity constructed in the Japanese language does not have a connection with another part of her identity constructed later with the acquisition of the new language and new culture, as she explains in one of her works (Mori, I997, p. 4), is it possible to replicate the thoughts and experiences expressed in one language again in another? Maybe it was only possible by a third translator, for whom it was not "my story".

\section{"Hearts of Non-Western People" or "Stereotypes"?}

As was discussed in Part two, Mori writes as an American writer, and her works are studied as a part of literature produced by 
bilingual authors (Pavlenko 200I), immigrant literature (Watanabe 2006, 2009; Kobayashi 2013) and Japanese-American literature (Zitlow and Stover I 998; Narasaki 2005), both in US and Japan. And yet, as was mentioned in the introduction, in Japan her work was presented by the publisher (and would have been received by some readers) as a part of Japanese literature. In this section, we will see various images and expectations surrounding Shizuko's Daughter, which at times seem to be contradicting each other.

It would be helpful to look at some paratexts, such as cover, title, table of contents or glossary, as they "implicitly convey information about the publisher's intention and contribute to form the image of Other" (Rovira-Esteva, 2016, p. I90). The original English hardcover (First Ballantine Books Edition: New York) shows an image that gives away some messages. It is a photograph of an Asian (supposedly Japanese) girl in blue kimono, sitting on a stone with a sad expression on her face. The photograph looks very old, due to her extremely simple hairstyle, her kimono, and her face without makeup. However, the story takes place mainly in I970s Kobe, and daily wear for both men and women had long been completely westernised. The protagonist, Yuki, does not wear a kimono even once in the story. This anachronism could be a reflection of what is expected of Japan as told in the story.

The English version has a glossary of Japanese cultural terms used in the story, such as futon or tempura. However, it is surprising that it has only eight entries including some historical terms already translated into English (e.g. "land reform"). Considering that the entire story takes place in Japan, an extremely small number of Japanese cultural terms are used. There is also a short note on the setting, which provides brief explanations about Japanese geography (Kobe, Nagasaki, etc.) and the school year (from April to March). These sections are attempts to make another culture described in the novel as accessible as possible to readers in the U.S. The very small number of Japanese cultural terms used indicates that the author used English terms which were considered to be culturally equivalent. It can mean sacrificing the details, as will be seen in Part four, discussing the translation.

The use of culturally equivalent terms is similar to the idea of domestication (Venuti, I995) in translation studies, which is 
about translating the text to sound fluent and natural in the target language, by minimizing its foreignness. According to Venuti, it is a dominating Anglo-American translation culture (Venuti, I995, p. 2I). Whereas the glossary and the note on the setting are there in order to draw the readers closer to understanding another culture, the domestication approach tries to draw the other culture closer to the readers. These efforts do not seem to contradict certain expectations about having a near-authentic cultural encounter through reading the text. Zitlow and Stover (I998) argue in an online article that "Reading literature, which offers the closest approach to living through the actual experiences of life, is the way to come to know something about a country and its people whether they remain in that country or move to another," in discussing the educational use of Japanese-American literature in the U.S. They recommend Shizuko's Daughter as it "takes readers inside the hearts and minds of non-western people." Though they state that Japanese American writers do not write their fiction "with a predefined purpose to teach others", they assure us that through Mori's novel "the reader learns about the Japanese rituals Yuki observes, particularly with her grandparents; about the Japanese attitude toward nature in beautiful scenes where Yuki's grandparents tend their gardens" amongst other things. The novel is expected to provide cultural information on Japan, yet some of their examples would leave Japanese people puzzled: “in Japan one does not smile at or talk to total strangers; in conversation formality, not emotions, governs encounters with people; only women hug each other; and there is an established custom about initially declining food offered by others."

It may not be surprising that such expectations exist. As Watanabe $(2006$, p. 49) points out, "It is certain that her works belong to U.S. literature, as they are written in English, though the settings are in Japan. On the other hand, they also could be called Japanese literature though written in English, as not only the settings, but all the personages are Japanese ${ }^{2}$." It is true that Shizuko's

${ }^{2}$ My translation from Japanese: モリの小説の設定は、日本ではある が、英語で書かれているのだから、アメリカ文学ということになる。 しかし、一方では、英語で書かれているものの、設定だけではなく、 
Daughter talks only about Japanese people in Japan, though in her later works, some non-Japanese characters and settings also start appearing. Watanabe states that Mori's works often elaborate on longings for the dead mother and rancor against the father and the stepmother, and they are almost like Shishōsetsu (I-novel), a genre in Japanese literature that talks about the author's personal life: “There is a contradiction. Mori rejects Japan saying that it is not her homeland but only a place she visits in her trips, but then in her works, she only writes about Japan. Despite being a Japanese person, she does not write nor speak in Japanese. However, the world about which she keeps on writing in English is limited only to $\operatorname{Japan}^{3} "$ (p. 49).

It was suggested earlier that Mori seems to have used the domestication approach to describe Japanese culture in English. Though it is a term normally used for translation, the process of writing about Japanese culture in English as in the case of Shizuko's Daughter could be similar to the translation process. This idea of domestication can be developed further in order to discuss if the author took such an approach in selecting the cultural elements described in the novel. That is to say, describing Japan or Japanese culture in a way that fulfils the existing images or expectations within the target (U.S.) culture. Throughout the novel, readers find beautiful descriptions of nature (flowers and trees from different seasons), as well as various traditional Japanese rituals and customs, such as the inauguration of a new house, a funeral, and a wedding. We have already seen Zitlow and Stover (I998) mentioning these points as examples of cultural information. However, these very points are criticised acutely by some Japanese researchers. For example, Watanabe (2006, p. 54) writes "It is also possible to argue that the beautiful Japanese sceneries or old Japanese traditions Mori describes would create

登場人物もすべて日本人であることから、日本文学ともいえるもので ある。

3 My translation from Japanese: すなわち「故郷ではない」「旅先にす ぎない」と言って日本を拒否するモリであるのに、作品の中では、日 本のことだけを書いているという矛盾が生じている。日本人でありな がら日本語を書いたり話したりしない一方で、モリが英語で書き続け る世界は日本のことに限定されている。 
exoticism that would please westerners, including Americans, and by hinting at orientalism, she is playing up to them. We can say that Mori, who hates Japan, is using just one aspect of it when it is convenient for her ${ }^{4}$." In a similar tone, Narasaki (2005, p. 67) argues that in today's Japanese American literature, a tendency to use Japanese culture in order to cater to American readers is still present. In relation to the Shizuko's Daughter, Narasaki mentions Owaki (2004, cited in Narasaki 2005, p. 76) warning about the possibility of "reproducing orientalism", and he himself argues that since "Mori is a first generation Japanese American, she is in the position to be able to explain today's Japan to American society. However, she keeps on writing almost stereotypical images of Japanese culture and people, which would be questioned by any Japanese person ${ }^{5}$ (p. 75)." What Zitlow and Stover (I998) called the "minds and hearts of non-western people" is called "almost stereotypical” by Narasaki. Narasaki's comment can also be read as an expectation for Mori to explain the reality of today's Japan to American society. However, describing a different/ foreign culture without being influenced by (or yielding to) the generalizations and stereotypes that exist in the majority culture is not easy. It can be extremely difficult when it has to be done in the language of the majority culture, in which one has to establish oneself as a professional writer.

Finally, there is the question of how the novel was presented in the Japanese market by the publisher. The actual translation of the text is discussed in Part four, but here the discussion will focus on other elements or paratexts. The cover image of the paperback version (published from Kadokawa Shoten, Tokyo) is an illustration - a profile of a short haired Asian girl standing in a white shirt, her

${ }^{4}$ My translation from Japanese: しかし、見方を変えれば、モリの描く 美しい日本の風景や古くから日本にある慣習は、アメリカ人を含む西 洋人を喜ばせるような異国情緒を作り上げ、オリエンタリズムの香り を漂わせて彼らにへつらっているということになる。日本を嫌ってい るモリが、日本の一面だけを都合よく利用しているにすぎないとも言 える。

5 My translation from Japanese: 世代論から言えば、日系一世にあたる Moriは、現代の日本をアメリカ社会に伝えることのできる立場にい るにもかかわらず、日本人なら首を傾げたくなるようなステレオタイ プに近い日本文化や日本人像を書きこんでいる。 
face meditative with eyes closed. She must be Yuki, who cuts her hair very short at one point in the story. The girl is loosely enclosed in vines, which show leaves and flowers of lily and chrysanthemum, maple leaves (all of them appear in the novel). With her eyes closed, the vines almost look like a representation of her internal world. There is no girl in an old-style kimono such as on the cover of original English version, and Japanese-ness is not emphasized in an obvious manner, though images of plants can be connected to the beauty of nature. In fact, this aspect of the book is strengthened in the Japanese version. For example, the copy used when the book was first translated in I995 stated "Kobe, a city full of beautiful flowers." Another example is to be found in the chapter titles of the Japanese version. The novel has I 5 chapters and an epilogue, and in the original version, each chapter has a title summarising some episode, such as "Housebound," "The Wake" and so on. In the Japanese translation, all I 6 chapter titles are plant names, such as "Sakura," "Shiragiku" (cherry blossom and white chrysanthemum respectively) etc., though the original English titles are also written underneath. Though all I 6 plant names do appear in their respective chapters, in the original English version only 5 chapters are named after plants, and this change must have been made to create a certain image of the novel. Emphasizing a sensitivity towards the beauty of nature and various seasons actually does fit the stereotype held in Japan about traditional Japanese culture (e.g. Asquith and Kalland, I996).

Another aspect emphasized in the Japanese market was the fact that it was "re-imported," as appeared in the copy. Though it is something familiar, there is something foreign, a hint of "otherness" at the same time. The translation of the title would be a good example. The title of the Japanese version is Shizukozu Dōta, a transcription of the English original title written in $k a-$ takana (a Japanese script used to write foreign words), without really translating it into Japanese. The name of the author was also written in katakana, rather than using original Chinese ideograms for her name.

Maybe the mixed expectation for the novel presented in the Japanese market can be summarised as something familiar yet foreign. Both aspects are emphasized. However, based on what we 
have seen in this section, it might even be possible for Japanese readers to perceive "otherness" through reading the text on Japanese culture domesticated for the U.S. audience. This, in itself, would not be such an unusual phenomenon. For example, Ogawa (2009, p. I4I) who translated Memoir of a Geisha by A. Golden into Japanese, claims that the attractiveness of the original novel was in its "exoticism about Japan," and though he made numerous corrections of cultural and historical facts in his translation, it was to reproduce this attractive virtual reality (and therefore not to eliminate the exoticism) convincingly in Japanese language. Can we say the same for Shiukozu Dōtä? In order to answer this question, we will see how the actual text was translated into Japanese.

\section{The Role of Translation}

Part four will discuss some points that became clear through the comparison of the ST (Source Text - original English version) with the TT (Target Text - Japanese translation), considering the relation of the translation with various expectations surrounding the novel that have been discussed in the previous section. Unlike the original text, which was expected to provide information about another culture, the Japanese version was presented to the market as something familiar yet foreign. What role has translation played to make this change possible?

Shizuko's Daughter was translated into Japanese by Makiko Ikeda, and the first thing to notice through the comparison of the ST and the TT is the small number of mistranslations, omissions or major changes. The cases of mistranslation and missing information are at a minimum, and unlike some cases of translating texts which entail clear exoticism about Japan into Japanese, there were no obvious major changes and manipulation of the original text (Inose, 20I7).

This seemingly almost "perfect" translation could be the result of several factors. First of all, in translating a culturally re-imported text (in this case, translating a text written in English about Japan into Japanese), the translator might assume some roles which are not required in a normal translation. For example, the translator might fill the gaps that exist due to the different levels of background cultural knowledge of the ST and TT readers. Since the TT 
readers are mostly Japanese, one can expect that they would have much more knowledge about the Japanese culture, customs, etc., described in the novel than the readers of the original English version. Then the translator needs to correct mistakes in historical or cultural facts if there are any in the original. It is also necessary to choose Chinese ideograms to write names of Japanese personages according to the Japanese custom (provided that they are correct Japanese names, which is not always the case). Some expression or conversation might sound unnatural if spoken by Japanese persons. In this case, the translator has to decide whether to respect the original or use some domestication technique. These translation problems could occur frequently if the ST author were not too familiar with Japanese culture or language. However, as this is not the case with Mori, these gaps do not occur often. All personages have typical Japanese names, so the translator would not have had any problem in choosing appropriate Chinese ideograms.

There are some conversation lines and expressions that sound rather unnatural when spoken by Japanese people - for example, Shizuko tells her daughter, Yuki, how much she loves her:

ST: "Yuki " she said. "Be good. You know I love you." (p. 4)

TT: "Yuki. Iikoni ne. Kāsan ga Yuki wo aishiteru koto wakatteru deshō.” (p. 9)

("Yuki, be good. You know mum loves Yuki.")

The translator uses the word aishiteru, which means "(to) love", which is a loyal translation of the ST. However, the use of this term in a conversation between mother and daughter is extremely unusual. Indeed, it might be unusual to express one's emotion towards the interlocutor so openly, but when it is done, the common word to use would be daisuki (to be very much fond of), which is less formal. However, as in the last telephone conversation between Shizuko and Yuki, the line is extremely important in the story, and probably could not be compromised for this reason, though the phrase in Japanese sounds rather "translated". Another example is:

ST: "It would be unkind of you not to let me go." (p. I06)

TT: "soredemo ikasete kurenai to shitara, sensei wa fushinsetsu desu." (p. I32)

("If you still don't let me go, teacher, you are unkind.") 
The line is spoken by Yuki to the teacher of domestic science, in front of the whole class. Again, it sounds rather unnatural for a Japanese to comment on the person one is speaking to (especially a teacher) so openly, and using the word fushinsetsu (unkind). This is not only because it is impolite, but the term fushinsetsu, though a correct translation of the word "unkind", would be much less used than the spoken word ijiwaru (mean) in a similar situation. These correctly translated, but rather unnatural Japanese lines might hint at "something foreign" to the readers, but these cases are quite rare.

Secondly, though it is not only for the re-imported text, translation of conversational language into Japanese requires the translator to choose an appropriate speech style for each speaker. Japanese has an extremely elaborate system of various registers, and vocabulary including pronouns, verbs and particles used in conversation can vary greatly according to factors such as gender, age, social class, educational level of the speaker, as well as social hierarchy or degree of formality between the speaker and the interlocutor. A particular speech style can be chosen to give a certain image to a personage (Kinsui, 2003), and in the case of translating a text into Japanese, it is an unavoidable addition of nuance, if not meaning. In Shizukozu Dōtā, three generations of women, namely Masa-Shizuko-Yuki, use completely different speech styles from each other. Masa speaks using almost gender-neutral speech, using sentences ending with the particle $d a$ (e.g. onegaidal please), very informal expressions (e.g. atashira/we, wasurechimatta/I have forgotten) and also expressions close to what Kinsui calls rōjingo or aged people's speech (e.g. tsureteitte okure/please take me along). It has no similarity whatsoever with the speech style of her daughter, Shizuko, who speaks in old fashioned and extremely feminine language. She uses sentence endings such as kashira (Yuki wa doko ni ittano kashira/I wonder where Yuki has gone), wayo (ii wayo/no problem) or the soft order form rasshai na (matte rasshai na/wait there). It is classical feminine language, which is used less and less nowadays (Yamanaka, 2008), but would have been common in the I960s and 70 s when Shizuko spoke those lines. It is exactly the kind of Japanese feminine language that, Mori claimed, forced women to sound "elaborately 
polite, indirect, submissive and unassertive" (Mori, I997, p. I2). Yuki's stepmother also uses this speech style.

Probably the most striking addition of nuance by the translator Ikeda in this aspect is the choice of speech style for Yuki. Yuki, again, speaks the language in a completely different way than her mother. In the novel, she grows from I 2 to I 8 years old, though her speech style does not change with age. She can speak quite rough language (e.g. Ippatsu omimai shite yatta yo/ I punched him), and generally her speech is closer to male language (e.g.tōsan to kāsan no koto wo kangaete itandal I was thinking of mum and dad) or more precisely, very gender neutral (which at times makes it sound like written language). She sounds frank and abrupt, and it is an unusual speech style which clearly avoids the use of typical feminine language. It might be an appropriate choice as Yuki seems to refuse to grow up to fit into the typical role of woman presented by the society (represented by the father and the stepmother), which also seems to coincide with the attitude of Mori (Usui, 2002, p. 6I).

Thirdly, as it is a culturally re-imported text, the translator uses strategies similar to back-translation in her treatment of the cultural terms. For these terms, the translation process is similar to translate "back" to Japanese, what was once translated into English. As discussed in the previous section, Mori uses the domestication approach to describe Japanese cultural references in English. For example, many terms are de-culturalized by using cultural equivalence (e.g. "goblin" to refer to the Japanese traditional ogre oni, or "robe" instead of using the Japanese word kimono) or generalization (e.g. "salted fish" as a translation of shiozake, salted and grilled salmon, or "chant" as a translation of norito, chanted prayer by a Shinto priest). These are both translation techniques to adapt the text to the target culture, though in some rare cases, Mori also keeps Japanese terms and adds explicatory words (e.g. "kikuna, edible spring mums"). The most important example of such de-culturalization in the novel is treatment of religious cultural terms. In Japan, Shintoism and Buddhism are both present in people's daily lives, not necessarily as religious practice, but as customs. As Shizuko's Daughter describes events such as weddings, funerals, and death anniversaries, there are many terms related to both Shintoism and Buddhism. For example, the 
weddings take place within the Shinto tradition, whereas the funeral and ancestor worshipping are part of Buddhist practices. Mori, however, does not distinguish between these two religions - for example, the word "priest", without any added explanation, is used for both kannushi (Shinto priest) and sōryo (Buddhist priest). They both "chant" (norito is a Shinto prayer by a kannushi wearing a white kimono and carrying a wand, for example at a wedding. In comparison, okyō is a Buddhist prayer by a sōryo, wearing a black kesalkimono and hair completely shaven, for example at a funeral). By seeing "the priest" at her father's wedding, Yuki remembers "another priest (p. 25)" at her mother's funeral - but in general, kannushi and sōryo are regarded as two different things that are not closely associated to each other. The same applies to the use of the words "temple" (jinja is a Shinto shrine and tera is a Buddhist temple) and "altar" (kamidana is a Shinto altar that enshrines gods whereas butsudan is a Buddhist altar which enshrines the spirits of ancestors). Though Mori also uses the term "Buddhist altar" later in the novel (p. I 28), in general she has de-culturalized and eliminated many differences between two religious traditions in Japan, which might make sense as a part of the domestication approach, but would be extremely unnatural if translated into Japanese. In other words, it would have been another "otherness" Japanese readers might have perceived in the text. However, Ikeda has translated these numerous de-culturalized and generalized terms into differentiated Japanese words. So the cultural nuances which had been eliminated in the ST have been recovered in the TT, in order to adapt the text to Japanese readers. School system (e.g. the ST talks of "eighth grade" etc., whereas in the Japanese system it would be the second year of junior high school) and measurement units are other examples that are translated "back" to the Japanese system in the TT. Thus, the possible feeling of otherness are eliminated, which could also be considered a practice of domestication.

The fourth point concerns tone changes in translation, which could also be a part of the adaptation of the TT to the target audience. As mentioned at the beginning of this section, Ikeda's translation has very few cases of errors or mistranslations. However, as we have seen, it does not mean that the ST and TT carry an equal amount of information (especially cultural information). Unlike 
adding (or restoring) cultural information to the de-culturalized terms, tone changes are subtle and sometimes it is not clear if they are conscious decisions taken by the translator. Still, these changes might have worked to reduce would-be unnatural sounding expressions in Japanese. For example:

ST: They are the adults, I shouldn't have to teach them about respect. (p. I35)

TT: Minna wa otona nandakara, keii ni tsuite minna ni osekkyō nanka suru beki ja nakatta. (p. I68)

(They are the adults, I shouldn't have preached to them about respect)

This is Yuki reflecting after having an argument with relatives of her mother's side. The tone is softer in the TT and Yuki regrets her action, whereas in the ST, she sounds annoyed that she had to explain her situation to the adults, who should know and understand better. Another interesting example is:

ST: There was already a lot of talk about how our country should send soldiers to occupy China. (p. I I9)

TT: Sonokoroniwa mou nihon wa heitai wo okutte Chūgoku wo senryō surunda tte in uwasa ga tobikatteta. (p. I48)

(There were many rumors at the time that Japan would send soldiers to occupy China)

The tone change is subtle, but it is clearly there. The speaker here is Kimura, a male friend of Shizuko, telling Yuki about the time of the Second Sino-Japanese war. In the ST, the speaker takes a more active stance in relation to the event ("our" country "should" send soldiers), whereas in the TT, the same event sounds a bit more distant, not directly related to the speaker. Considering that Kimura was just a child at the time of the event, maybe he did feel like it was something distant - but the translation also would have the effect of softening the feeling of proactively initiating the war, when read by Japanese readers. It is argued that the mention of a great historical event that happened to the country of origin is one of the typical features of ethnic minority literature in the U.S. (Kobayashi, 2013, p. 76). Shizuko's Daughter also talks about Japan during the war and about the land reform (in which the parents of Shizuko lost their land) that took place under the U.S. 
occupation, though these are not main themes in the novel. The tone change above might indicate that these topics are even less central in the Japanese translation.

Finally, it seems that the Japanese TT has a stronger effect on readers to identify with Yuki's viewpoint. This is partially due to a Japanese language tradition - when one talks to a younger person, he or she often refers to himself or herself using a term that reflects his/her relation with that younger person. So, for example, Aya's (Yuki's aunt) speech to Yuki is translated as follows.

ST: After this, you won't see me very often anymore. (p. 23)

TT: Kekkonshiki ga sundara, obachan niwa amari awanai hou ga iiwa. (p. 33)

(After the wedding, it is better not to see the auntie so often.)

This is applied to all the adults surrounding Yuki, such as her father, mother, or grandparents. Instead of using "I", they all talk to Yuki referring to themselves as tōsan (dad), kāsan (mum) etc. And this is not only in their speech lines, but also in the narrative parts, the names of personages such as Aya, Shizuko, Masa, Hideki etc. in the ST are often translated as obalobachan (aunt/auntie), haha (mother), sobo (grandmother), chichi (father) and so on, and thus they are constantly redefined in relation to Yuki rather than acting as independent personages. Though in Japanese all this does not sound unnatural (rather, it sounds very natural), the viewpoint offered by the text would shift and everything is narrated more from Yuki's viewpoint in translation.

\section{Conclusion}

The present study has considered issues surrounding a re-imported text, or a text that crosses language and cultural borders several times, such as different expectations regarding the text and the role of translation. It became clear that on the two sides of the crossed border, the text was presented by the publisher, and received by the reader to fulfil somewhat different expectations. Foreign touch, or otherness, is emphasized in presenting both the original English and Japanese translations, though it means different things in the two versions. Readers were told that they could learn about another culture by reading the original version, and 
the publisher provided measures, such as glossary, to make it easier. The text itself makes it easier for the target readers by adopting domestication approach in handling cultural references. However, this approach has been acutely criticised by some Japanese researchers as not only inauthentic, but almost a reproduction of the exoticism and stereotypes about Japan that exist in the western world.

The otherness searched in the Japanese version is more complicated, as it has to be something foreign within the familiar. This would have occurred, though it might not have been in the way intended by the publisher, if the translation maintained the numerous cultural omissions (domestication approach mentioned above) appearing in the ST. It would have shown how Japanese culture could be presented outside Japan - an unfamiliar view of the familiar. However, by recovering all the omitted cultural information and changing the tones of some expressions, the Japanese translation eliminated the unnaturalness that Japanese readers could have felt. Moreover, by adding extra nuances through the choice of an unusual but appropriate speech style for Yuki and re-orientating the viewpoint of the reader to identify more with her, it might be possible to say that the Japanese translation more strongly represents Yuki's personal story than the original. Thus the "something foreign" is limited to the positioning of the novel by the publisher as re-imported literature, and a few other elements such as the book title, but the actual text is translated to be read as the personal story of a Japanese girl in Japan, without anything "foreign within the familiar." In a way, it could give readers the impression of reading something different without experiencing uncomfortable discrepancy in cultural understanding, which might have been one of the causes of its success in Japan. The text was domesticated each time it crossed the border, having been re-imported and thus causing it to go through the process not only once, but twice.

\section{Acknowledgements}

This research was funded by Åke Wibergs Stiftelse Foundation (Sweden). 


\section{References}

Asquith, P.J. and Kalland, A. (I996). Japanese Images of Nature: Cultural Perspectives. Routledge: London and New York

Inose, H. (2016). "Not Crossing the Boundary: The Untranslatable in Japanese-English Bilingual Literature," in Nordin, I., Edfeldt, C., Hu, L., Jonsson, H., and Leblanc., A. (eds.) Transcultural Identity Constructions in a Changing World. Frankfurt am Main: Peter Lang, pp. 219-234.

- (2017). Literature Translation as Re-Importation: When the Text Travels Twice Between Cultures [PowerPoint presentation given at The $8^{\text {th }}$ Asian Translation Tradition Conference, London].

Kinsui, S. (2003). Vācharu nihongo yakuwarigo no nazo [The mistery of virtual Japanese language]. $\mathrm{I}^{\text {th }}$ edn. Tokyo: Iwanami Shoten

Kobayashi, E. (2013). "An Analysis of Jean Rhys's Voyage in the Dark and Autobiographical Novels by Asian Americans," Wayo Joshi Daigaku Kiyō, 53, pp. 7 I-82

Masubuchi, C. (I996). "Shizuko's Daughter - Eigo de kataru kako [Shizuko's Daughter - the past written in English]," Gakushüin Daigaku Jinbunkagaku Ronshu, , , pp. 93-106

Mori, K. (I993). Shizuko’s Daughter. New York: Ballantine Books

- (I999). Shizukozu Dōtā. Translation from English to Japanese by Ikeda, M., paperback edition. Tokyo: Kadokawa Shoten

- (1995). The Dream of Water. New York: Henry Holt and Company, Inc.

- (1997). Polite Lies. New York: Henry Holt and Company, Inc.

- (2000). Becoming Midwestern, in Danquah, M.N. (eds.) Becoming American: Personal Essays by First Generation Immigrant Women. New York: Hyperion, pp. I38-I45

Narasaki, H. (2008). "Japonism and Americanism in Japanese American Literature: Beyond Race and Generation," Otsuma Journal of Comparative Culture, 9, pp. 67-83

Ogawa, T. (2009). Honyaku no himitsu [The secret of translation]. Tokyo: Kenkyūsha 
Owaki, M. (2004). "Tashaka saseru 'nihon no onna' - Kyoko Mori to David Mura no nihon no onna no hyōshō ['Japanese women' being made into 'the Other' - representations of Japanese women by Kyoko Mori and David Mura]," in Ebine, S. and Takemura, K. (eds.) Kakumo tasai na onna tachi no kiseki [Such diversified trajectories of women]. Tokyo: Nanundō, pp. 237-258

Rovira-Esteva, Sara (2016). "The (Mis)Use of Paratexts to (Mis) Represent the Other: Chun Sue's Beijing Doll as a Case Study," Onomázein, núm.34, diciembre, pp. I87-208

Pavlenko, A. (200I). "In the World of the Tradition, I was Unimagined: Negotiation of Identities in Cross-Cultural Autobiographies," The International Journal of Bilingualism 5 (3), pp. 3 I 7-344

Usui, M. (2002). “The Trauma Caused by Mother's Deaths in Virginia Woolf and Kyoko Mori," Doshisha Literature, 45, pp. 59-8I

Venuti, L. (I995) The Translator's Invisibility: A History of Translation, London and New York: Routledge

Watanabe, K. (2006). "Kyoko Mori no sokoku nippon - shin imin no tachiba kara [Kyoko Mori's homeland, Japan - seen from the position of a new immigrant]," Tokyo Seitoku Tanki Daigaku Kiyo, 39, pp. 47-55

- (2009). "Kyoko Mori no saishinsaku ni mirareru henyō [The changes seen in the latest work by Kyoko Mori]," Tokyo Seitoku Tanki Daigaku Kiyō, 42, pp. I23-134

Yamanaka, Y. (2008). "Gendai nihongo no seisa ni kansuru kenkyū [Research on gender difference in today's Japanese language]," Studies in Language and Culture, I7, pp. 87-100

Zitlow, C. and Stover, L. (I998). "Japanese and Japanese American Youth in Literature," The Alan Review, 25 (3). [Online]. Available at: http://scholar.lib.vt.edu/ejournals/ALAN/spring98/zitlow.html (Accessed: Io September 20I7). 